\title{
APAKAH PRAKTIK PUBLIC RELATIONS SUDAH SIAP MENGELOLA KRISIS KOMUNIKASI PADA ERA 4.0 ?
}

\author{
Martha Tri Lestari ${ }^{1}$, Hadi Purnama ${ }^{2}$, Choiria Anggraini ${ }^{3}$ \\ Telkom University, Bandung, Indonesia
}

\begin{abstract}
ABSTRAK
Penelitian dalam artikel ini secara utuh menggambarkan bentuk kesiapan korporasi di Indonesia dalam menghadapi krisis secara digital. Akan tetapi berdasarkan hasil riset menggunakan metode analisis isi kuantitatif terhadap beberapa artikel berita terkait krisis korporasi pada sample sebuah korporasi di Indonesia terlihat tidak didapatkan kesiapan sebuah korporasi tersebut dalam menghadapi krisis komunikasi secara digital. Hal ini menjadi satu catatan tersendiri dalam gambaran kesiapan public relations dalam korporasi di Indonesia dalam menghadapi era dalam mengelola krisis secara digital. Peneliti merekomendasikan tahapan pengelolaan krisis dalam lima tahap mulai dari: identifikasi stakeholder; crisis stage; crisis cluster; crisis respon; dan sampai pada tahap pemilihan media dalam mengantisipasi penanganan krisis korporasi di era aplikatif melalui media digital.
\end{abstract}

Kata-kata Kunci: public relations, komunikasi krisis, komunikasi korporasi

\section{ARE PUBLIC RELATIONS PRACTICES READY TO MANAGE COMMUNICATION CRISIS IN THE 4.0 ERA?}

\begin{abstract}
The research in this article fully describes the form of readiness of corporations in Indonesia to face a digital crisis. However, based on the results of research using quantitative content analysis methods on several news articles related to the corporate crisis in a sample of a corporation in Indonesia, it seems that there is no readiness of a corporation in facing a digital communication crisis. This is a separate note in the description of public relations readiness in corporations in Indonesia in facing the era of managing a digital crisis. Researchers recommend the stages of crisis management in five stages starting from: identification of stakeholders; crisis stage; crisis cluster; crisis response; and arrive at the media selection stage in anticipation of handling the corporate crisis in the applicable era through digital media.
\end{abstract}

Keywords : Public Relations, Crisis Communication, Corporate Communication

\section{PENDAHULUAN}

Komunikasi Korporasi merupakan hal yang penting dan prosesnya selalu dilakukan pada setiap Korporasi baik pada level internal maupun eksternal.
Saat ini pola perubahan komunikasi dari yang awalnya era konvensional telah berubah pada era konvergensi (digital). Melihat hal tersebut, peneliti tertarik ingin mengkaji sebuah penelitian yang 
mengangkat bagaimana sebuah Korporasi menangani proses Komunikasi Korporasi yang saat ini dilakukan secara digital terutama untuk menangani kasus-kasus yang dapat dikategorikan menjadi sebuah Krisis dalam sebuah Korporasi. Krisis menjadi satu bagian yang akan terus melekat pada proses pertumbuhan korporasi karena krisis bersifat inevitable, yakni situasi yang dimungkinkan menerpa suatu perusahaan meskipun sudah diantisipasi sebelumnya (Coombs, 2007; Kriyantono, 2015). Krisis merupakan situasi yang tidak diharapkan, membuat situasi tidak stabil dan penuh ketidakpastian, menimbulkan kepanikan, dapat menghasilkan kerusakan fisik dan nonfisik, memengaruhi operasional perusahaan, dan pada akhirnya mengancam reputasi (Fearn-Banks, 2011; Kouzmin, 2008). Korporasi yang mengalami krisis memerlukan manajemen krisis sebagai upaya mengatasi permasalahan akibat krisis (Chen, 2012; Devlin, 2007).

"A set of factors designed to combat crises and to lessen the actual damages inflicted... seeks to prevent or lessen the negative outcomes of a crisis and thereby protect the organization, stakeholders, and/or industry from damage." (Coombs, 2010)

Meski demikian perlu dipahami lebih jauh bahwa sebenarnya krisis tidak dipicu oleh peristiwanya, tetapi sebagai akibat dari tindakan penanganan krisis tersebut (Harrison, 2005). Hal ini termasuk tentang interpretasi dan reaksi publik dan manajemen terhadap peristiwa itu (Zyglidopoulos, 1999). Terlebih krisis "intangible in the minds of people" yang terlibat di dalamnya (Culbertson, Jeffers, Stone, \& Terrell, 1993), yang memungkinkan membuat situasi krisis membesar. Kemungkinan ini semakin mungkin terwujud dengan adanya migrasi digital dalam pola komunikasi.

Terlebih krisis sangat bergantung pada persepsi individu- individu yang terkait (Penrose, 2000). Oleh karena hal tersebut persepsi individu lebih menentukan perkembangan krisis daripada fakta objektifnya itu sendiri (Brunett, 1998).

Pada situasi krisis yang menjadi realitas bukan hanya fenomenanya sendiri tapi lebih mengakar pada hasil persepsi individu (Regester dan Larkin, 2008). Hal ini juga merujuk pada fakta bahwa persepsi merupakan inti komunikasi (Mulyana, 2009). 
Persepsi sendiri sangat ditentukan oleh kualitas informasi yang diberikan korporat (Kriyantono, 2012). Oleh karena itu, menyediakan serta mengontrol arus informasi secara akurat dan efisien merupakan indikator mengatasi krisis. Maka jika gagal akan menjadi kesalahan terbesar, tetapi jika berhasil tentu akan menjadi kesuksesan dalam mengatasi krisis (Duhe, 2005; Duke \& Masland, 2002; Wigley \& Zhang, 2011).

Oleh karena itu kesulitan terbesar dalam mengatasi krisis adalah kegagalan dalam mengontrol lingkungan yang diakibatkan oleh rumor-rumor, opini karyawan atau komunitas maupun dampak psikologis- sosial-budayaekonomi yang dirasakan publik (Brunett 1998). Mengontrol lingkungan ini merupakan salah satu domain Public Relations, bukan hanya di saat krisis tetapi juga di saat normal (Toth, 2002). Tetapi bagaimana cara Public Relations akan mengontrol domain ini pada arus migrasi digital 4.0?. Terlebih mengingat domain yang dimainkan oleh public relations ini hanya didominiasi oleh komunikasi, sedangkan komunikasi sendiri merupakan esensi sebuah manajemen krisis (Combs, 2010). Belum lagi di era digital ini, teknologi mempengaruhi secara berulang cara korporasi menjalankan perusahannya dan memberikan servis kepada konsumen (Imran, 2019)

Akan tetapi agaknya hal ini tidak sepenuhnya dapat dimplementasikan dengan komprehesnsif oleh korporasi di Indonesia, hal ini terbukti dengan salah satu contoh sebuah korporasi maskapai di Indonesia yang sedang mengalami krisis. Krisis ini berawal ketika bea cukai mendapati bahwa terdapat sebuah kasus penyelundupan sepeda bermerek dengan nilai puluhan sampai ratusan juta dalam moda transportasi tersebut. Kasus penyelundupan ini sampai berimbas pada kasus lain yang muncul pada korporasi tersebut yang mengakibatkan krisis sumber daya manusia.

Pada pengumpulan data pra - riset, peneliti tidak menemukan sikap penangan krisis melalui platform digital yang diambil oleh pihak manajemen yang berperan disini adalah unit Public Relations maskapai terkait, namun pada sisi lain kasus ini semakin membesar melalui digital word of mouth yang dihasilkan oleh masyarakat digital 
(netizen), sehingga hal ini menjadi agak timpang jika dibandingkan dengan peran utuh Public Relations dalam penangan krisis.

Merujuk pada hal tersebut, peneliti melihat sebuah urgenitas untuk dapat melakukan sebuah riset guna melihat kesiapan Korporasi melalui unit Public Relations dalam melakukan penanganan Manajemen Krisis Komunikasi yang dihasilkan oleh kecepatan media digital dalam menyebarkan isu-isu yang dapat menimbulkan krisis dalam korporasi.

Kesiapan ini peneliti lihat dari pemberitaan serta respon krisis secara digital yang diberikan oleh korporasi selama masa krisis. Pertama, peneliti menguraikan situasi krisis yang sedang dialami oleh korporasi menggunakan sudut pandang dari teori situasional crisis communication, jenis, serta tahapan krisis.

Pertama, situasional crisis communication theory (SCTT). SCCT mengidentifikasi situasi krisis yang mempengaruhi atribusi publik terhadap reputasi. Reputasi merupakan aset organisasi yang tidak terlihat (intangible) namun berpotensi rusak ketika organisasi megalami krisis
(Coombs \& Holladay, 2002). Menyediakan mekanisme melalui komunikasi krisis, SCCT merupakan teori yang didesain untuk melindungi reputasi ketika krisis dan mempertahankan melalui strategi krisis yang efektif (Coombs, 2007).

SCCT membagi jenis krisis menjadi tiga kelompok klaster krisis berdasarkan tingkat kerusakan yang ditimbulkan. Klaster krisis ini merupakan hasil atribusi publik terhadap krisis tentang siapa yang harus bertanggung jawab (Kriyantono, 2014). Mengumpulkan dari beberapa literatur seperti Combs (2007), Kim (2014) dan Kriyantono (2012), tiga klaster krisis tersebut terdiri dari: (1) Klaster korban (victim cluster), (2) Klaster kecelakaan (accidental cluster. (3) Klaster kesengajaan (intentional cluster).

Selanjutnya, jika dilihat dari jenisnya, Kriyantono (2015) menjelaskan terdapat tujuh jenis krisis yakni diantaranya: (1) krisis teknologi, (2) krisis konfrontasi, (3) krisis malevolence, (4) Krisis menejemen, (5) Workplace violence, (6) bencana alam, dan (7) krisis produk.

Terakhir, penelitian ini juga 
menganalisis objek penelitian dari tahapan krisis yang terbagi menjadi empat tahap menurut Fink (1986). Pertama, (1) prodomal atau tahapan adanya indikasi terjadinya krisis, (2) accute atau terjadinya krisis, 3) chronic yakni periode pemulihan atas krisis yang dialami, dan tahapan keempat adalah ketika perusahaan dapat melakukan aktivitas normal lagi atau dalam fase kondisi krisis masuk dalam tahap (4) crisis resolution.

\section{METODE PENELITIAN}

Metodologi penelitian yang digunakan oleh peneliti dalam penelitian ini adalah metode kuantitatif berdasarkan pendekatan positivistik. Metode ini dijalankan dengan teknik pengambilan data analisis isi kuantitatif sebagai salah satu metode pembacaan pesan yang sistematis dan komprehensif.

Selanjutnya, sampling pada penelitian ini adalah pemberitaan krisis sebuah korporasi terkait pada rentang waktu sekitar satu minggu. Berita yang dijadikan sampel adalah berita yang dimuat pada portal berita nasional seperti detik.com, liputan 6.com, tribunenews.com, yang memiliki peringkat tertinggi pada Alexa tahun
2019. Total sample berita yang didapatkan adalah sebanyak 83 artikel berita.

Operasionalisasi Variabel pada penelitian ini berdasarkan 2 (dua) justifikasi teori, yakni variabel situasional crisis respon theory dan crisis cluster. Dua variabel ini digunakan untuk menganalisis dan membaca artikel berita terkait guna mengetahui kesiapan korporasi dalam menghadapi krisis melalui media digital.

\section{HASIL DAN PEMBAHASAN}

Terdapat 83 artikel berita yang dijadikan sample objek penelitian menunjukkan secara keseluruhan kasus yang sedang menimpa sebuah maskapai yang berada pada cluster intentional. Hal ini ditunjukkan dengan jumlah keseluruhan tensi pemberitaan. Akan tetapi, tidak ada strategi dominan yang diambil oleh korporasi guna menangai krisis ini. Hanya ada 2 (dua) strategi yang tergambar dalam 3 (tiga) artikel berita yakni strategi deny dan dimish. Dua strategi ini pun juga tidak membantu dalam menangani krisis, karena tidak sesuai dengan kluster krisis yang tengah menimpa korporasi terkait, sehingga tidak terlihat metode penanganan krisis 
secara digital oleh korporasi. Diluar hal tersebut, peneliti melihat adanya opini yang terbentuk dari masyarakat yang sudah terbangun melalui diskusi secara digital . Data opini ini peneliti ambil melalui sumber digital yaitu droneemprit.id.

Data opini digital dari masyarakat atas kasus yang tengah dialami oleh maskapai tersebut mengarah pada tone negatif, sehingga tentunya menjadi persoalan tersendiri ketika hal tersebut tidak direspon oleh korporasi. Hal ini dapat dianggap sebagai sebuah salah satu indikasi ketidak siapan sebuah korporasi dalam beradaptasi serta bertransformasi secara digital dalam konteks penanganan krisis. Imbas lain akibat kasus ini adalah korporasi harus mengalami penurunan nilai saham yang cukup signifikan. Lalu bagaimana seharusnya penanganan krisis di era 4.0 ini dimulai oleh korporasi yang tengah mengalami krisis?

Manajemen stakeholder memberikan sebuah penjelasan yang komprehensif terhadap cara membangun relasi perusahaan dengan berbagai pihak yang terkait dengan kegiatan operasional perusahaan untuk mencapai superior performance. Oleh karena hal tersebut, penting bagi perusahaan untuk mengidentifikasi kelompok pengaruh ini terlebih dalam keadaan krisis. Hal ini bertujuan untuk dapat melakukan prediksi terhadap perasaan dan tindakan yang akan dilakukan oleh publik dalam situasi tersebut.

Lebih dari itu, sebuah korporasi pun perlu memiliki pemahaman dan pendekatan yang tepat terhadap para stakeholder yang menjadi mitra terlebih ketika sedang mengalami krisis. Terlebih saat ini masyarakat berada di era digital yang dapat menyebabkan informasi dalam berbagai bentuk dapat menyebar dengan sangat cepat dan mengakibatkan isu-isu berkembang sangat cepat dan mengarah baik pada tone positif, megatif ataupun netral.

Hal seperti ini yang menuntut seorang Public Relations sebagai garda terdepan pada sebuah perusahaan untuk dapat peka terhadap isu-isu yang berpotensi menimbulkan krisis bagi korporasi yang bersangkutan, salah satunya tentang Manajemen stakeholder dalam situasi krisis.

Oleh karena hal tersebut diatas, pemahaman tentang stakeholder dan pengolahannya menjadi sebuah dasar 
yang harus dikuasi korporasi untuk dapat mengontrol dan memprediksi segala bentuk permasalahan dan perubahan lingkungannya. Hal itupun yang membuat sebuah korporasi harus dapat memfasilitasi dan membawa stakeholder untuk dapat membangun nilai-nilai dan pemahaman bersama tentang korporasi terkait.

Terdapat istilah mengenai Slippery slope to socialism, yang dapat diartikan bahwa korporasi harus menjadi lebih terbuka kepada publik atau lebih transparan atas setiap aktivitas perusahaan yang berkenaan dengan kepentingan-kepentingan stakeholder; Adjudicator vs utilitarian rationality, objective yang dapat diartikan bahwa korporasi disarankan untuk dapat melibatkan stakeholder dalam mengambil keputusan-keputasan atas tindakan yang memiliki indikasi terhadap stakeholder.

Hal-hal tersebut dapat berdampak positif bagi korporasi hanya jika perusahaan mampu melakukan beberapa hal didukung oleh unit Public Relations sebagai garda terdepan dalam sebuah korporasi. Dapat peneliti berikan simpulan bahwa seorang Public Relation dalam menangani krisis komunikasi khususnya pada era digital seperti saat ini, maka mereka harus mempersiapkan beberapa hal penting, seperti : (1) membandingan antara kekuatan dan kepentingan yang dimiliki oleh stakeholder, (2) membuat participation planning matrix, (3) membuat daftar kepentingan- kepentingan stakeholder, (4) menyusun argumen dan perancanaan yang baik terhadap stakeholder, (5) merangkul stakeholder leader untuk dapat menyampaikan argumen dan perencanaan yang telah dibuat oleh korporasi kepada stakeholder yang lain, (5) membuat diagram isu-isu yang mungkin muncul atas keberadaan korporasi, (6) membuat analisis etika terhadap penyelesaian isu yang muncul, (7) membuat stakeholder role play, (8) membuat analisis kebijakan yang ditentukan dengan kemampuan stakeholder, dan terakhir (9) membuat dan mengembangkan strategi pengimplementasian Manajemen stakeholder yang saat ini perlu adanya penyesuaian implementasi melalui media digital.

Perumuskan beberapa strategi yang harus dijalankan untuk melakukan 
pendekatan pada stakeholder, pemetaan dan analisis maka selanjutnya diantaranya yakni: (1) signifikan, Public Relations memahami tahapan memahami secara komprehensif isu krisis guna menentukan langkah strategis yang menjadi fokus stakeholder dan penanganan krisis. Hal ini merujuk pada korporasi, (2) completeness, memahami betul kebutuhan, keinginan, dan harapan dari stakeholder, dan terakhir (3) responsiveness, memberikan respon secara koheren dan pada porsinya. Korporasi, dalam rangka mengimplementasikan ketiga prinsip tersebut juga harus memperhatikan beberapa hal diantaranya: communication, yakni korporasi dituntut untuk dapat mendengarkan aspirasi stakeholder dan menyampaikan respon korporasi dengan baik, (2) transparan, memberikan data dan penjelasan yang telah disetujui, (3) inclusiveness, melibatkan stakeholder dalam setiap aktivitas pengambilan keputusan, dan yang keempat (4) integrity, memperlakukan stakeholder secara hormat dan etika yang baik. Empat hal tersebut jika ditarik lebih dalam juga dapat diartikan bahwa korporasi harus melibatkan stakeholder secara emosional dalam setiap aktivitas korporasi yang berkenaan dengan stakeholder.

Kedua, setelah selesai pada fakta yang pada dasarnya krisis ini dapat dihindari ketika perusahaan mampu mengidentifikasi sebuah krisis berdasarkan tahapannya. Terdapat empat tahapan terjadinya krisis yang disampaikan, yaitu (1) prodomal atau tahapan adanya indikasi terjadinya krisis, (2) accute atau terjadinya krisis, 3) chronic yakni periode pemulihan atas krisis yang dialami, dan tahapan keempat adalah ketika perusahaan dapat melakukan aktivitas normal lagi atau dalam fase kondisi krisis masuk dalam tahap (4) crisis resolution.

Akan tetapi sayangnya, tidak banyak penelitian yang mengungkap tentang tindakan-tindakan yang dilakukan seorang profesional communication dalam situasi penanganan krisis dalam setiap tahapannya. Pada tahap pre crisis, perusahaan harus mampu mengidentifikasi resiko dengan menjadi “big ear" untuk mengumpulkan indikasiindikasi potensi terjadinya krisis, menjadi fasilitator dengan pemikiran yang terbuka, serta mampu memahami sebuah ketidak normalan yang tengah terjadi. 
Selanjutnya, pada tahap crisis atau saat kirisis tengah terjadi, sebuah korporasi (public relations atau professional communication) dituntut untuk dapat mengambil peran sebagai pembuat pesan yang masuk akal atas penjelasan krisis yang terjadi, menjadi jembatan komunikasi dari berbagai pihak yang berkepentingan untuk dapat menyelesaikan krisis, dan berperan sebagai communication consellor. Pada tahapan krisis yang terkahir yakni post crisis, korporasi harus mampu mengambil pelajaran dari krisis yang terjadi sebagai sebuah tindakan antisipasi pada masa mendatang. Hal ini juga yang diindahkan oleh korporasi dalam kasus pada penelitiannya.

Ketiga, setelah proses identifikasi stakeholder dan tahapan krisis, hal selanjutnya yang harus ditentukan dengan tepat adalah kluster krisis. Pada dasarnya krisis ini dapat dihindari ketika korporasi mampu mengidentifikasi sebuah krisis berdasarkan klasternya.

Keempat, setelah selesai mengidentifikasi segala penyebab dan dampak krisis yang timbul maka public relations harus mampu dengan tepat menentukan respon yang akan diambil guna menghadapi krisis. Ketepatan respon ini menjadi satu hal yang esensial dan harus tepat karena Pada dasarnya publik memiliki atribusi tertentu tentang krisis. Atribusi publik yang dibangun sangat menentukan reputasi organisasi. Oleh karena itu setiap tindakan yang dilakukan oleh organisasi ketika krisis berpengaruh langsung terhadap reputasi organisasi pada masa yang akan datang.

Dengan mengetahui jenis krisisnya, seorang Public Relations seharusnya dapat menentukan strategi crisis response yang efektif bagi korporasi. Crisis response merupakan fase penting yang perlu diperhatikan oleh korporasi, karena segala tindakan yang dilakukan oleh korporasi saat dan sesudah krisis memiliki pengaruh yang siginifikan terhadap ancaman reputasi. Oleh karena hal tersebut maka setiap tindakan yang dilakukan oleh seorang Public Relations haruslah tepat dan efektif untuk mengurangi efek krisis tersebut, dengan cara memberikan informasi yang sebenarnya kepada publik tentang hal yang sedang terjadi dan yang harus dilakukan saat krisis.

Langkah lain yang dapat dilakukan adalah menentukan media digital yang 
akan digunakan untuk menyampaikan pesan-pesan komunikasi terkait krisis tersebut. Pemilihan media digital akan sangat bergantung pada poin pertama tentang identifikasi stakeholder. Hal lain yang harus dipertimbangkan adalah tentang karakteristik tiap media digital yang berbeda-beda tergantung jenis krisis dan karakter publik yang akan disasar oleh korporasi. Karakteristik ini berkaitan dengan keterjangkauan korporasi kepada stakeholder serta memastikan pesan-pesan komunikasi dapat diterima dengan baik oleh stakeholder khususnya dalam konteks krisis yang tengah menerpa korporasi tersebut.

\section{SIMPULAN}

Merujuk pada hasil pemaparan hasil pengolaan data penelitian, dapat di tarik sebuah simpulan umum bahwa salah satu contoh kasus krisis korporasi yang menimpa salah satu maskapai di Indonesia tersebut berada pada kluster intentional. Hal ini dikuatkan dengan sample data yang menunjukkan bahwa seluruh statement pada data yg dijadikan objek penelitian menunjukkan bahwa kriris ini disebabkan oleh pelanggaran hukum yang dilakukan oleh korporasi terkait yang pada kasus ini adalah sebuah maskapai penerbangan. Akan tetapi, meski demikian dari data yang peneliti kumpulkan tidak terlihat penanganan krisis secara gamblang yang dilakukan oleh korporasi guna meredam tone opini negatif di masyarakat terlebih secara digital. Hal ini menyebabkan citra korporaso maskapai tersebut menjadi terancam dan secara tidak langsung berpengaruh pada nilai saham. Secara general, korporasi tersebut belum mampu merespon krisis dengan mempertimbangkan kluster krisis yang menimpa secara linier.

Hal ini tentu menjadi sebuah catatan awal tentang kesiapan korporasi dalam menghadapi krisis di era digital. Hal ini mengingat bahwa pada era 4.0, opini begitu mudah terbentuk dan menyebar sehingga krisis pun juga akan dengan mudah berkembang. Setidaknya catatan awal ini dapat menjadi satu rujukan penanganan krisis di era digital oleh praktisi Public Relations pada korporasi yang berada di Indonesia.

\section{DAFTAR PUSTAKA}

Abramenka, V. (2013). Content analysis of british petroleum and tokyo electric power company's crisis communication message: A comparative analysis of crisis communication strategies. Master 
Thesis.

Anthonissen, P.F. (2008). Crisis communication: Practical PR strategies for reputation management and company survival. London: Kogan Page.

Burnett, J. J. (1998). A strategic approach to managing crisis. Public relations Review, 24(4), 475-488.

Coombs, W. T., \& Holladay, S. J. (2002). Helping crisis managers protect reputational assets:Initial test of the situational crisis communications theory. Managemen communication quaterly, 16, 165.

Coombs, W. T. (2006). The protective powers of crisis response strategies: Managing reputational assets during a crisis. Journal promotions managemen, 12 (3/4), 241-258.

Coombs, T. (2007). Protecting organization reputation during a crisis: The development and application of situational crisis communication theory. Corporate Reputation Review, 10(3), 163176.

Coombs, W. T. (2010). Parameters for crisis communication. In W. T. Coombs \& S. J. Holladay (Eds.), The Handbook of Crisis Communication. West Sussex: Wiley-Blackwell. Corporate Reputation Review, 10(3), 163176.

Coombs, W. T. (2015a), Ongoing Crisis Communication. Planning, Managing, and Responding (fourth edition), Sage Publications, Inc., Thousand Oaks, California
Chen, Z. (2012). Crisis communication and reputation management: A content analysis of a chinese highspeed rail accident. (Unpubished thesis). Bale State of University, Muncie, Indiana.

Culbertson, H. M., Jeffers, D. W., Stone, D. B., \& Terrell, M. (1993). Social, Political, And Economic Contexts In Public Relations: Theory and Cases. New Jersey: Lawrence Erlbaum Associates Publisher.

Cutlip, S. M., Center, A. H., \& Broom, G. M. (2011). Effective Public Relations (B. S. Tri Wibowo, Trans. 9 ed.). Jakarta: Kencana Prenada Media.

Departement Of Imigrant And Citizenship. (2008). Stakeholder Engagement: Practioner Handbook. Australia: Author.

Donaldson, T., \& Preston L.E. (1995). The stakeholder theoryof the corporation: Concepts, evidence, and implication. Academy of Management Review, 20 (1), 65-91.

Freeman, R.E., Harrison, J., Hicks, A., Parmar, B., \& and Colle, S. (2010). Stakeholder theory: The state of the art. New York: Cambridge University Press.

Freeman, R.E., \& McVea, J. (2001). A stakeholder approach to strategic management (Graduate Thesis). Tersedia di Social Science Research Network Electronic Paper Collection. (No 01-02).

Freeman, R.E., Wicks, A.C., \& Parmar .B. (2004). Stakeholder theory and "the corporate objective revisited". Organization Science, 5 (3), 364369. 
Grunig, J., \& Hunt, T. (1984). Managing Public Relations. New York: Holt, Rinehart and Winston. Heide, M., \& Simonsson, C. (2012). Developing internal crisis communication new roles and practices of communication professionals.

Corporate Communications: An International Journal. 19 (2), 128146. Fearn-Banks, K. (2011). Crisis Communication: A Casebook Approach. New Jersey: Lawrence Erlbaum.

Harrison, G. (2005). Communication Strategies as a Basis for Crisis Management Including Use of the Internet as a Delivery Platform. Dissertation. Georgia State University. Georgia.

Imran, A.Y. (2019). The Effect Of Technological Behavior Towards The Adoption Of Education Integrated System Among New Intake Students. Jurnal Lingkar Studi Komunikasi, 5(1), 29-39.

Kim, S. M. (2014). The use of situational crisis communication theory in Korea (Dissertation). Retrieved from ProQuest Dissertation \& Thesis.

Kouzmin, A. (2008). Crisis management in crisis? Journal of Administrative Theory and Praxis, 30 (2), 155-183.

Kreps, G. L. (1990). Organizational Communication (2 $\quad$ ed.). California: Sage publications.

Kriyantono, R. (2014a). Teori public relations perspektif barat dan lokal: Aplikasi riset \& praktis. Jakarta: Prenada

Kriyantono, R. (2014b). Teknik Praktis
Riset Komunikasi: Disertai Contoh Praktis Riset Media, Public Relations, Advertising, Komunikasi Organisasi, Komunikasi Pemasaran (5 ed.). Jakarta: Kencana Prenada Media.

Kriyantono, R. (2012a). Measuring a company reputation in a crisis situation: An ethnography approach on the Situational Crisis Communication Theory.

International Journal of Business and Social Sciece, 3(9), 214-223.

Kriyantono, R. (2016). Public Relations Writing: Teknik Produksi Media Public Relations dan Publisitas Korporat (cetakan ke-3, 2 ed.). Jakarta: Kencana Prenada Media.

Kriyantono, R. (2015). Public relations \& crisis management: Pendekatan critical public relations, etnografi kritis \& kualitatif. Jakarta: Prenada media.

Lattimore, D., Baskin, O., Heiman, S. T., \& Toth, E. L. (2010). Public Relations: The Profession and the Practice (2 ed.). New York: McGraw Hill.

Mitroff, I.I. (2001). Managing crisis before they happen. New York: Amacom.

Penrose, J. M. (2000). The role of perception in crisis planning. Public relations Review, 26(2), 155-171.

Regester, M., \& Larkin, J. (2008). Risk Isues and Crisis Management in Public Relations: A Casebook of Best Practice. London: Kogan Page.

Sugiyono. (2011). Metode penelitian kuantitatif kualitatif dan $R \& D$. Bandung: Alfabeta. 